\title{
Effects of soil compaction on seedling morphology, growth, and architecture of chestnut-leaved oak (Quercus castaneifolia)
}

\author{
Meghdad Jourgholami ${ }^{(1)}$, Azadeh \\ Khoramizadeh $^{(1)}$, Eric K Zenner ${ }^{(2)}$
}

\begin{abstract}
Soil compaction following traffic by heavy-timber harvesting machinery usually causes an increase in soil strength, that is a stress factor negatively affecting the growth of newly germinated seedlings. This study used a soil strength experiment carried out in a greenhouse to test the hypotheses that increasing soil strength would adversely affect seedling morphology and alter seedling architecture by changing biomass allocation patterns. We explored the effects of soil compaction in a loam to clay-loam textured soil with optimal conditions of water on a continuous scale (0.2-1.0 MPa penetration resistance) on growth responses of the deciduous Quercus castaneifolia (C.A.Mey). Both above- and below-ground seedling characteristics, including size and biomass, were negatively affected by soil compaction. At the highest intensity of compaction, size and growth were reduced by $50 \%$ compared to controls; negative effects were typically more severe on below-ground (i.e., the length and biomass of the root system) than on above-ground responses. Increasing soil strength did not change above- and below-ground biomass allocation patterns (i.e., root mass ratio, root:shoot ratio, specific root length), resulting in unchanged seedling architecture. Strong adverse effects were already evident in the low-intensity compaction treatment and no critical soil strength threshold was observed. We conclude that root and height growth in $Q$. castaneifolia seedlings is limited by any increase of soil strength, though no evidence for the disruption of a functional equilibrium between above- and below-ground plant portions was found up to soil strengths of $1.0 \mathrm{MPa}$, at least under optimal water supply.
\end{abstract}

Keywords: Hyrcanian Forest, Penetration Resistance, Growth, Chestnut-leaved Oak, Relative Growth Rate.

tion (Horn et al. 1994), and saturated hydraulic conductivity (Grace et al. 2006). Increased soil compaction is associated with a greater proportion of micropores (Dickerson 1976) and increased soil strength (i.e., increased resistance of soil particles to displacement or soil penetration resistance) for all but soils of low bearing capacity (Horn et al. 1994, Ampoorter et al. 2007).

Plants typically exhibit a wide range of responses to increased soil strength, i.e., physiological adaptations that affect morphogenesis, architecture, and nutrient and water use (Kozlowski 1999, Masle 2002, Bassett et al. 2005). Shortly after soil
(1) Department of Forestry and Forest Economics, University of Tehran, Zob-e-Ahan Street, 315854314 Karaj (Iran); (2) College of Agricultural Sciences, Pennstate University, 305 Forest Resources Building, University Park, 1680 PA (USA)

@ Meghdad Jourgholami (mjgholami@ut.ac.ir)

Received: May 29, 2015 - Accepted: Feb 14, 2016

Citation: Jourgholami M, Khoramizadeh A, Zenner EK (2016). Effects of soil compaction on seedling morphology, growth, and architecture of chestnut-leaved oak (Quercus castaneifo(ia). iForest 10: 145-153. - doi: 10.3832/ifor1724-009 [online 2016-06-13]

Communicated by: Renzo Motta strength increases, the elongation rate of primary and lateral roots decreases, the root cap generally becomes more rounded, and the root diameter behind the meristem (root tip) increases (Eavis 1967). As a consequence, morphological traits of roots can change: main roots become shorter and more lateral branch roots are formed, the proportions of fine roots and root xylem vessels are reduced, volume and weight of the root system decrease, and rooting depths become more shallow (Corns 1988, Misra \& Gibbons 1996, Kozlowski 1999, Bejarano et al. 2010, Alameda \& Villar 2012). A smaller root system and more shallow rooting depths result in lower amounts of uptake of major nutrients and water, lower rates of transpiration and photosynthesis, and higher leaf water deficits (Kozlowski 1999). Mechanical forces on roots trigger a signaling cascade throughout the plant, resulting in direct physiological effects on leaves and stomata, such as reduced leaf expansive growth and reduced stomatal conductance (Masle 2002). Thus, increased soil strength can heighten plant stress (Kozlowski 1999), reduce overall plant seedling growth performance (i.e., total plant weight, shoot weight, branch weight, shoot height, and stem diameter - Jordan et al. 2003, Alameda \& Villar 2009, Bejarano et al. 2010), 
and ultimately enhance baseline seedling mortality beyond levels from exposure to typical environmental stresses (Acácio et al. 2007). Young woody seedlings that need to develop effective roots to obtain water and nutrients or face the risk of reduced survival may be particularly sensitive to adverse effects of increased soil strength on root growth (Misra \& Gibbons 1996).

The magnitude of the threshold soil strength that can lead to significant physiological effects has been much debated (Masle 2002). A critical soil strength above which woody plant root elongation is severely restricted is believed to be in the vicinity of 2-2.5 MPa, depending on soil type and species (Day \& Bassuk 1994), but it appears that root growth of woody plants may be restricted with any increase in soil strength (Skinner et al. 2009). Restricted root growth does not necessarily translate into a reduction of total plant biomass (Blouin et al. 2008), which is affected by soil type and texture (Gómez et al. 2002), climate (Greacen \& Sands 1980), light (Bejarano et al. 2010), water and nutrient availability (Gómez et al. 2002, Blouin et al. 2008), species (Alameda \& Villar 2009), and soil strength (Kabzems \& Haeussler 2005, Alameda \& Villar 2009). In fact, total biomass of Quercus pyrenaica Willd. seedlings responded positively to increased soil strength under high, but not low, light conditions (Bejarano et al. 2010). Similarly, total biomass of several deciduous and evergreen tree species responded positively to increased soil strength up to 0.5 MPa, but not beyond (Alameda \& Villar 2009). Further, the relationship between increasing soil strength and different seedling growth responses may not always be linear and different thresholds of soil strength may exist for different growth responses (Alameda \& Villar 2009).

Root-shoot interactions of woody perennials in response to increased soil strength are complex with respect to plant architecture and growth allocations to above- and below-ground portions of woody plants (Bulmer \& Simpson 2005, Siegel-Issem et al. 2005). Increased soil strength may change the proportional growth allocation between above- and below-ground portions of seedlings (Corns 1988, Bassett et al. 2005, Alameda \& Villar 2009, 2012) and decrease the proportion of roots (Kozlowski 1999). It is unclear, however, whether changes in total plant biomass are consistently associated with changes in growth allocation patterns. If so, then structural traits of stems and roots that change with increased soil strength may not simply dis tort plant architecture (Alameda \& Villar 2009), but might indeed be seen as indicators of a resource-limited feedback between shoot and root growth serving to achieve a new balance between aboveand below-ground portions of trees.

In this study, we quantified the relationship between different intensities of soil compaction and a set of above- and belowground responses of chestnut-leaved oak (Quercus castaneifolia C.A.Mey) seedlings to test the main hypotheses that increasing soil strength (1) causes morphological (size) changes to above- and below-ground portions of the seedlings, (2) causes decreased growth (biomass) responses of the whole plant and all of the plant's components (e.g., stem, shoot, leaves, roots), (3) causes differential growth allocation patterns to above- and below-ground portions that result in architectural changes to the seedlings, (4) is not linearly related to all growth response variables, and (5) has to exceed differing thresholds for different response variables before significant responses can be detected.

\section{Materials and methods}

\section{Study area}

The soil material used in this study area came from a Hyrcanian (Caspian) forest stand in the Namkhaneh District of the Kheyrud forest research station (Iran). The region is characterized by brown soils (cambisols) that are the most abundant soil type and cover $90 \%$ of the Hyrcanian region. The specific soil of this study area, which was located at an elevation below $700 \mathrm{~m}$ a.s.l., has the following characteristics: semi-calcareous brown soils with a loam to clay-loam texture; $A_{1} A_{2} B_{1} B_{t} C$ profile with an average profile depth of $1.05 \mathrm{~m}$ and a maximum depth of $1.6 \mathrm{~m}$ (Jourgholami 2014); 20-65\% water content; $11 \%$ organic matter content; 5.8-6.8 pH $\left(\mathrm{H}_{2} \mathrm{O}\right) ; 14.7 \mathrm{C} / \mathrm{N}$. On lower slopes below $700 \mathrm{~m}$ a.s.l., chestnut-leaved oak and common hornbeam (Carpinus betulus L.) are mixed with ironwood (Parrotia persica C.A.M.), forming the communities Querco-Carpinetum and Parrotio-Carpinetum that are often characterized by two layers with oak in the upper and hornbeam in the lower story. The upper tree distribution limit depends on geomorphology, climate and soil; at higher altitudes chestnut-leaved oak prefers warm and sunny slopes.

Effects of soil compaction on chestnutleaved oak seedling growth were studied, because this light-demanding species is one of the most productive, valuable, and precious timber species of the Hyrcanian forests of northern Iran (Talebi et al. 2014). Growing in areas with mild climatic conditions and on gentle slopes that provide easy access for harvesting, a many-century long harvest history has greatly reduced the extent and abundance of oaks forests to about $8 \%$ of stem numbers and standing volume in the Hyrcanian forests. Natural regeneration of this species has become challenging, due to intensive cattle grazing and ground-based timber skidding that have led to highly compacted soils in oak forests. The degree and extent of mechanization of skidding operations has greatly intensified in the Caspian region over the last decade and there is concern about soil compaction and degradation and lack of oak regeneration, with attending consequences for run-off, soil erosion, and flood risk. Before expensive restoration plantings are being considered to regenerate oak, however, it is important to establish whether, and if so, to what extent soil compaction affects above- and belowground seedling growth and may thus be implicated in the regeneration difficulties.

\section{Sampling methods and measurements}

Loose soil to a depth of $30 \mathrm{~cm}$ was collected from the $A_{0}$ (litter), $A_{1}$, and $A_{2}$ horizon and transferred immediately to a temperature-controlled greenhouse in the College of Agriculture and Natural Resources at the University of Tehran in Karaj, Iran. The soil was placed into plastic pots where Q. castaneifolia seeds were sown on 25 December 2013; two weeks later (on 9 January 2014) the first seedlings began to sprout. Q. castaneifolia seedlings were grown with constant irrigation to avoid the possible confounding effects of different soil water regimes (Souch et al. 2004). Water was supplied uniformly on a daily basis using a sprinkler irrigation system ( 15 minutes of irrigation per day) and greenhouse conditions were controlled to be as similar as possible for all seedlings in terms of light, water, humidity and temperature throughout the entire experiment by shifting the position of the pots in the greenhouse during the growing season. To ensure that only seedlings with similar root sizes were used in the compaction experiment (i.e., to minimize pre-compaction size differences), on 29 February 2014, twenty seedlings of almost identical sizes were selected and transplanted into plastic pots large enough $(15 \mathrm{~cm}$ diameter $\times 50 \mathrm{~cm}$ height) to avoid possible space limitations for root growth over the course of the experiment (Alameda \& Villar 2012). Five seedlings (pots) were randomly assigned to each compaction treatment that was first imposed on the pot. Due to the unusually comprehensive range of above- and belowground seedling measurements undertaken in this study, relatively few seedlings could be investigated.

Similar to previous research (Alameda \& Villar 2009, Bejarano et al. 2010), we created four treatment intensities of increasing soil compaction. The lowest intensity of compaction (no compaction, control) consisted of simply filling the larger pot with the collected soil material without applying additional soil compaction measures; low, moderate, and high intensities of compaction were achieved by manually applying 3, 5 and 7 blows with a compaction hammer from a height of $20 \mathrm{~cm}$ above the soil surface, respectively (Bejarano et al. 2010). Each seedling was then planted into a small hole of a few centimeters made in the substrate into which the root was placed. The mean initial root length of the seedlings was $9.8 \pm 2.7 \mathrm{~cm}$. Soil penetration resistance (SPR) was used in this study as a 
measure of soil strength/compaction. SPR was quantified by taking measurements every $10 \mathrm{~cm}$ along the soil profile in each pot using a hand-held penetrometer; the five values were averaged for each pot. Bulk density was measured by taking one soil sample cores from each pot using a thin-walled steel cylinder of $20 \mathrm{~mm}$ length and $28 \mathrm{~mm}$ in diameter that was driven into the pot by a hammer-driven device. After extracting the steel cylinder from the pot at the end of the experiment, the soil cores were trimmed flush with the cylinder end. Samples were weighed on the day they were collected and again after drying at $105^{\circ} \mathrm{C}$ for 24 hours in a drying oven to determine water content and bulk density.

Bulk density was calculated as follows (eqn. 1):

$$
B D=M_{s} / V_{t}
$$

where $B D$ is the bulk density $\left(\mathrm{g} \mathrm{cm}^{-3}\right), M_{\mathrm{s}}$ is the mass of the soil $(\mathrm{g})$, and $V_{\mathrm{t}}$ is the volume of the cylinder $\left(\mathrm{cm}^{3}\right)$.

Soil porosity $(T P)$ was determined by the following equation (eqn. 2 ):

$$
T P=[(P D-B D) / P D] \cdot 100
$$

where $P D$ is the particle density measured by a Guy-Lussac pycnometer according to the ASTM D854-00 2000 standard and BD is the bulk density $\left(\mathrm{g} \mathrm{cm}^{-3}\right)$. A pycnometer is a device to determine the density of a liquid in reference to an appropriate working fluid, such as water or mercury, using an analytical balance; the device is usually made of glass, with a close-fitting ground glass stopper with a capillary tube through which air bubbles may escape.

Particle density $(P D)$ was determined as (eqn. 3):

$$
P D=\frac{d w \cdot W s}{W s-W s w-W w}
$$

where $d w$ is the density of water $\left(\mathrm{g} \mathrm{cm}^{-3}\right)$ at the temperature observed, $W s$ is the weight of soil sample (oven dry); Wsw is the weight of pycnometer, soil and water; and $W w$ is the weight of pycnometer and water.

Seedlings were grown in the larger treatment pots for 176 days (starting in late February) and harvested at the end of the first growing season (late August). Each plant was harvested by carefully extracting the plant from the pot, followed by washing the roots in a container of water. Seedling roots were gently dried and root length and fresh weights (biomass) of leaves, stems, and roots of each plant were measured. Dry weights (biomass) were obtained after drying leaves, stems, and roots at $70{ }^{\circ} \mathrm{C}$ until a constant weight was reached.

The following response variable means were measured or computed for each seedling: (1) morphological (size) responses [cm]: stem length, stem diameter, leaf length, main root length, main root diameter, lateral root diameter; (2) growth (dry biomass [g]) responses: total biomass, shoot biomass, stem biomass, leaf biomass, total root biomass, main root biomass, lateral root biomass; and (3) architectural responses: lateral/main root length ratio, lateral/main root dry biomass ratio, specific stem length (SSL: ratio of stem length to stem dry biomass), specific root length (SRL: ratio of fine root length to fine root dry biomass), leaf mass ratio (LMR: ratio of leaf dry biomass to total dry biomass), root mass ratio (RMR: the ratio of root dry biomass to total dry biomass), stem mass ratio (SMR: the ratio of stem dry biomass to total dry biomass), root-toshoot ratio (R/S: ratio of root to shoot dry biomass). Although biomass was measured as fresh and dry, the responses in this study are reported for dry biomass.

The experimental design was a completely randomized design whereby seedlings were randomly assigned to the compaction treatment. We applied general linear modeling (GLM, one-way analysis of variance) to relate seedling growth responses to soil penetration resistance (SPR). Since no departure of the data from a normal distribution was observed by the Kolmogorov-Smirnov test ( $\alpha=0.05)$, standard parametric analyses were carried out. Homogeneity of variance among treatments was verified by Levene's test ( $\alpha=$ 0.01). Post-hoc comparisons of compaction intensity treatment group means were performed using Duncan's multiple range test with a $95 \%$ confidence level. Treatment effects were considered statistically significant when $P \leq 0.05$. Because the soil compaction treatments resulted in a continuous range of SPR, we used regression models to enable prediction of the responses at various levels of SPR. Stepwise regression was used to identify whether linear or polynomial (second-order) models would result in the best fit, using $P \leq 0.05$ and adjusted $\mathrm{R}$-squared as the metric for inclusion of the higher-order polynomial. All statistical analyses were carried out using the SPSS (release 15.0) statistical package.

\section{Results}

\section{Compaction and porosity}

As designed, compaction treatments significantly increased soil penetration resistance from $0.27 \pm 0.03 \mathrm{MPa}$ in the control treatment to $0.84 \pm 0.06 \mathrm{MPa}$ in the high intensity compaction treatment $(P \leq 0.001)$

Tab. 1 - Mean ( \pm standard deviation) of soil compaction indices (i.e., penetration resistance, bulk density, and total porosity) in each of the four levels of compaction treatments investigated in this study.

\begin{tabular}{lccc}
\hline $\begin{array}{l}\text { Compaction } \\
\text { treatment }\end{array}$ & $\begin{array}{c}\text { Penetration } \\
\text { resistance }(\mathrm{MPa})\end{array}$ & $\begin{array}{c}\text { Bulk density } \\
\left(\mathrm{g} \mathrm{cm}^{-3}\right)\end{array}$ & $\begin{array}{c}\text { Total porosity } \\
(\%)\end{array}$ \\
\hline Control & $0.27 \pm 0.03$ & $1.16 \pm 0.14$ & $45.7 \pm 1.2$ \\
Low & $0.41 \pm 0.04$ & $1.29 \pm 0.09$ & $40.6 \pm 2.1$ \\
Moderate & $0.59 \pm 0.03$ & $1.42 \pm 0.11$ & $34.2 \pm 1.6$ \\
High & $0.84 \pm 0.06$ & $1.51 \pm 0.08$ & $30.3 \pm 1.4$ \\
\hline
\end{tabular}

and bulk density from $1.16 \pm 0.14 \mathrm{~g} \mathrm{~cm}^{-3}$ in the control to $1.51 \pm 0.08 \mathrm{~g} \mathrm{~cm}^{-3}$ in the high Compaction treatments significantly decreased total porosity from $45.7 \pm 1.2 \%$ in the control to $30.3 \pm 1.4 \%$ in the high intensity treatment $(P \leq 0.001)$.

\section{Seedling morphology (size)}

All of the morphological responses of $Q$. castaneifolia seedlings decreased significantly with increasing SPR (all $P \leq 0.001$ Tab. 2). Comparing values of the morphological responses in the control treatment to the high intensity compaction treatment revealed reductions of $61 \%$ in stem lengths, $58 \%$ in stem diameters, $43 \%$ in leaf lengths, $56 \%$ in main root lengths, $48 \%$ in main root diameter, and $72 \%$ in lateral root lengths (Tab. 2).

The relationships of the morphological responses to increasing SPR followed negative exponential curves (Fig. 1), indicating that reductions in the responses were greatest between the control and the low intensity compaction treatment and lower with increasing compaction intensity thereafter. This is also seen in the post-hoc comparisons of compaction intensity treatment group means, where Duncan's multiple range tests detected significant differences in all morphology responses between control, low, and moderate intensity compaction treatments, but did not detect significant differences between the moderate and high intensity compaction treatments in any of the morphological responses except lateral root length (Tab. 2). Further, leaf lengths did not significantly differ among low, moderate, and high intensity compaction treatments (Tab. 2).

\section{Seedling growth (biomass)}

All of the biomass variables of Q. castaneifolia decreased significantly with increasing SPR (all $P \leq 0.001-$ Tab. 2). Comparing values of biomass variables in the control treatment to the high intensity compaction treatment revealed reductions of $59 \%$ in total biomass, $53 \%$ in shoot biomass, $53 \%$ in stem biomass, $53 \%$ in leaf biomass, $63 \%$ in total, main, and lateral root biomass (Tab. 2).

The relationships of increasing SPR to some biomass variables (total biomass, stem biomass, total root biomass, and main root biomass) were nearly linear, while the relationships of leaf biomass and lateral root biomass followed a negative intensity treatment $(P \leq 0.001-$ Tab. 1). 
Tab. 2 - Means and standard deviations (in brackets) of variables of seedling morphology (size), growth (biomass), and architecture (allocation ratios) of Q. castaneifolia seedlings grown at different intensities of soil compaction. Different letters in a row indicate significant differences among intensities of soil compaction $(P<0.01)$ based on Duncan's multiple range tests.

\begin{tabular}{|c|c|c|c|c|c|c|}
\hline \multirow{2}{*}{$\begin{array}{l}\text { Seedling } \\
\text { characteristics }\end{array}$} & \multirow{2}{*}{ Variable } & \multicolumn{4}{|c|}{ Compaction intensity (mean + SD) } & \multirow{2}{*}{$\begin{array}{c}\text { One-way ANOVA } \\
\text { (p-value) }\end{array}$} \\
\hline & & Control & Low & Moderate & High & \\
\hline \multirow{6}{*}{$\begin{array}{l}\text { Morphology } \\
\text { (size) }\end{array}$} & Stem length $(\mathrm{cm})$ & $28.1(6.1)^{a}$ & $19.7(1.8)^{b}$ & $13.6(3.4)^{c}$ & $10.9(1.1)^{c}$ & $<0.001$ \\
\hline & Stem diameter $(\mathrm{mm})$ & $24.2(3.3)^{\mathrm{a}}$ & $17.4(1.3)^{\mathrm{b}}$ & $11.6(0.9)^{c}$ & $10.2(0.8)^{c}$ & $<0.001$ \\
\hline & Leaf length (cm) & $17.4(1.9)^{\mathrm{a}}$ & $14.3(1.8)^{\mathrm{b}}$ & $12.2(2.1)^{\mathrm{b}}$ & $9.9(1.7)^{b}$ & $<0.001$ \\
\hline & Main root length $(\mathrm{cm})$ & $29.3(4.1)^{\mathrm{a}}$ & $19.1(1.3)^{b}$ & $14.9(1.0)^{c}$ & $12.8(1.4)^{c}$ & $<0.001$ \\
\hline & Main root diameter $(\mathrm{mm})$ & $18.8(3.1)^{\mathrm{a}}$ & $14.8(0.8)^{\mathrm{b}}$ & $10.8(0.8)^{c}$ & $9.8(0.8)^{c}$ & $<0.001$ \\
\hline & Lateral root length $(\mathrm{cm})$ & $52.6(3.9)^{\mathrm{a}}$ & $34.8(4.8)^{\mathrm{b}}$ & $25.8(3.3)^{\mathrm{c}}$ & $14.8(2.0)^{d}$ & $<0.001$ \\
\hline \multirow{6}{*}{$\begin{array}{l}\text { Growth } \\
\text { (biomass) }\end{array}$} & Total dry biomass (g) & $65.9(5.8)^{\mathrm{a}}$ & $52.5(3.2)^{b}$ & $40.4(1.5)^{c}$ & $27.0(2.1)^{d}$ & $<0.001$ \\
\hline & Shoot dry biomass (g) & $26.6(2.4)^{\mathrm{a}}$ & $22.0(1.3)^{\mathrm{b}}$ & $16.7(2.3)^{c}$ & $12.4(0.9)^{d}$ & $<0.001$ \\
\hline & Stem dry biomass (g) & $15.5(2.5)^{\mathrm{a}}$ & $13.0(1.7)^{b}$ & $11.0(1.3)^{\mathrm{b}}$ & $7.3(1.0)^{c}$ & $<0.001$ \\
\hline & Leaf dry biomass (g) & $11.0(3.2)^{\mathrm{a}}$ & $9.0(0.6)^{a}$ & $5.6(1.1)^{b}$ & $5.1(1.1)^{b}$ & $<0.001$ \\
\hline & Main root dry biomass (g) & $39.3(4.1)^{\text {a }}$ & $30.5(3.8)^{b}$ & $23.7(1.7)^{\mathrm{c}}$ & $14.6(2.1)^{d}$ & $<0.001$ \\
\hline & Lateral root dry biomass (g) & $15.5(1.7)^{a}$ & $11.2(1.9)^{\mathrm{b}}$ & $10.0(0.5)^{b}$ & $5.6(1.5)^{c}$ & $<0.001$ \\
\hline Architecture & Lateral / main root length & $1.82(0.24)^{\mathrm{a}}$ & $1.83(0.22)^{a}$ & $1.73(0.23)^{a}$ & $1.16(0.15)^{\mathrm{b}}$ & $<0.001$ \\
\hline \multirow{7}{*}{ (allocation ratios) } & Lateral / main root dry biomass & $0.66(0.17)^{\mathrm{a}}$ & $0.57(0.14)^{\mathrm{a}}$ & $0.73(0.16)^{a}$ & $0.60(0.05)^{\mathrm{a}}$ & 0.304 \\
\hline & Specific stem length (SSL) $\left(\mathrm{cm} \mathrm{g}^{-1}\right)$ & $1.86(0.63)^{\mathrm{a}}$ & $1.55(0.33)^{\mathrm{a}}$ & $1.25(0.34)^{\mathrm{a}}$ & $1.52(0.24)^{\mathrm{a}}$ & 0.171 \\
\hline & Specific root length (SRL) $\left(\mathrm{cm} \mathrm{g}^{-1}\right)$ & $3.48(0.60)^{\mathrm{a}}$ & $3.30(0.51)^{\mathrm{a}}$ & $2.59(0.39)^{\mathrm{a}}$ & $2.85(1.12)^{a}$ & 0.226 \\
\hline & Stem mass ratio (SMR) & $0.24(0.04)^{\mathrm{a}}$ & $0.25(0.03)^{\mathrm{a}}$ & $0.27(0.03)^{a}$ & $0.27(0.02)^{\mathrm{a}}$ & 0.281 \\
\hline & Leaf mass ratio (LMR) & $0.17(0.04)^{\mathrm{a}}$ & $0.17(0.02)^{\mathrm{a}}$ & $0.14(0.02)^{a}$ & $0.19(0.05)^{\mathrm{a}}$ & 0.191 \\
\hline & Root mass ratio (RMR) & $0.60(0.02)^{a}$ & $0.57(0.05)^{\mathrm{a}}$ & $0.59(0.05)^{a}$ & $0.56(0.06)^{\mathrm{a}}$ & 0.563 \\
\hline & Root-to-shoot ratio (R/S) & $1.48(0.14)^{\mathrm{a}}$ & $1.37(0.21)^{a}$ & $1.46(0.31)^{\mathrm{a}}$ & $1.22(0.23)^{\mathrm{a}}$ & 0.286 \\
\hline
\end{tabular}

exponential curve, indicating that reductions in the latter biomass variables were greatest between the control and the low intensity compaction treatment and decreased with increasing compaction intensity thereafter (Fig. 2). Duncan's multiple range tests detected significant differ- ences among all compaction intensity treatments for total biomass shoot biomass, and main root biomass (Tab. 2). Stem biomass and lateral root biomass did not significantly differ among compaction treatments except between the low and moderate intensity compaction treat-

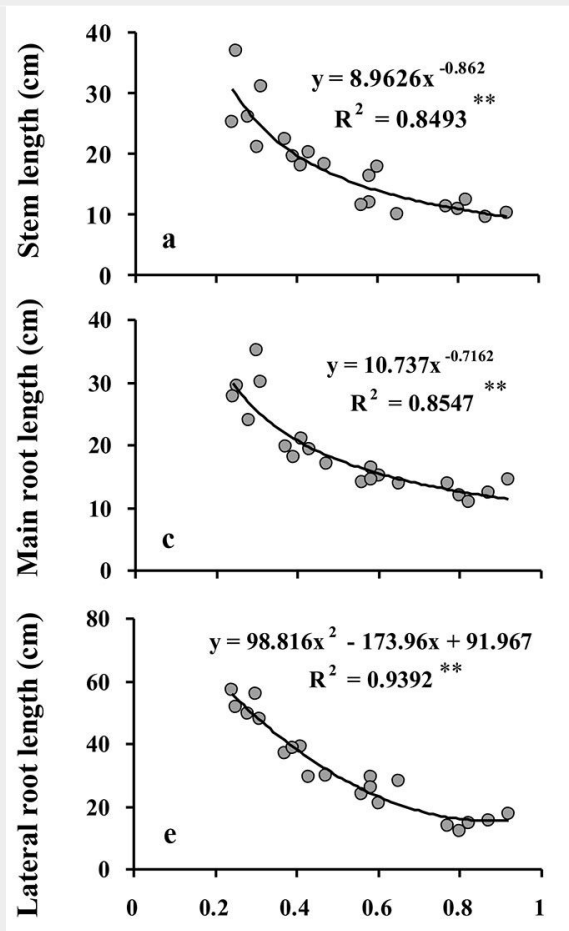

Penetration resistance $(\mathrm{MPa})$
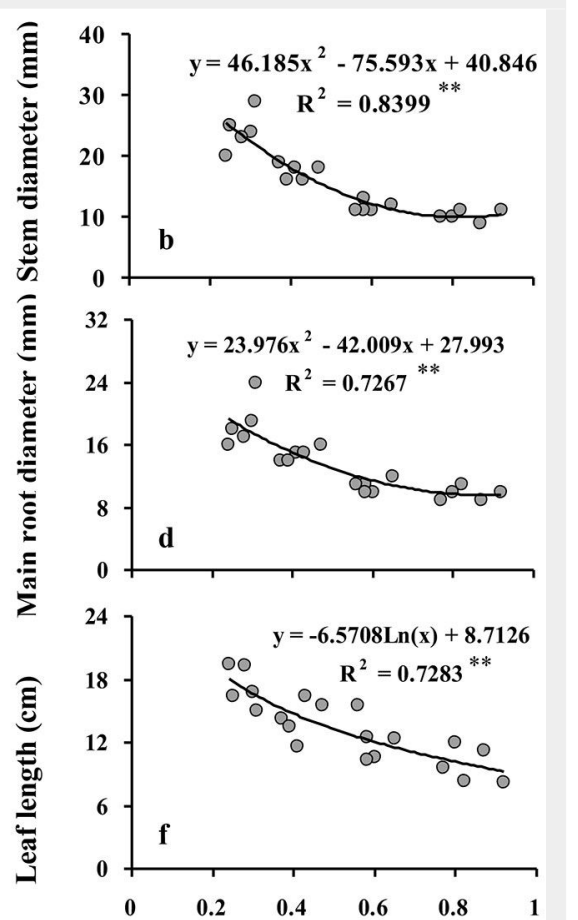

Penetration resistance $(\mathrm{MPa})$

Fig. 1 - Relationship between soil penetration resistance (SPR) and morphological responses of $Q$. castaneifolia seedlings: stem length (a), stem diameter (b), main root length (c), main root diameter (d), lateral root length (e), and leaf length (f). For each graph, the regression equation between responses and SPR and the coefficient of determination $\left(R^{2}\right)$ are given. $(*): P<0.05 ;(* *): P<0.01 ;(n s)$ : not significant $(P \geq 0.05)$.

ments. Further, leaf biomass was not significantly different between the moderate and high intensity compaction treatments; in addition, leaf biomass was not significantly different between the control and low intensity compaction treatments (Tab. 2).

Seedling architecture (allocation ratios) The ratio of lateral to main root length ranged from 1.82 in the control treatment to 1.16 in the high intensity compaction treatment and was significantly reduced (by $36 \%, P \leq 0.001$ ) only after soil compaction reached a high intensity; no significant differences were observed among the control, low, and moderate intensity treatments (Tab. 2, Fig. 3a). The ratio of lateral root to main root biomass was not significantly different among compaction treatments (Tab. 2, Fig. 3b).

Despite significant quadratic relationships indicate that a curvilinear response curve of specific stem length (SSL, the ratio of stem length to stem dry biomass) and specific root length (SRL, the ratio of fine root length to fine root weight) provided the best fit with increasing penetration resistance and with lowest values at moderate intensity compaction treatments (Fig. 3cd), SSL and SRL were not significantly different among compaction treatments (Tab. 2).

A significant quadratic relationship was also found between leaf mass ratio (LMR, the fraction of total dry biomass in the leaves of the seedlings) and increasing penetration resistance, indicating that lowest values of LMR were observed at moderate intensity compaction treatments (Fig. 3e); however, LMR, which ranged between $14-19 \%$, was not significantly different among compaction treatments (Tab. 2). Stem mass ratio (SMR) and root 
Fig. 2 - Relationship between soil penetration resistance (SPR) and biomass variables of $Q$. castaneifolia seedlings: total dry biomass (a), stem dry biomass

(B), leaf dry biomass (C), total root dry biomass (D), main root dry biomass (E), and lateral root dry biomass (F). For each graph, the regression equation between responses and SPR and the coefficient of determination $\left(\mathrm{R}^{2}\right)$ are given. $\left({ }^{*}\right)$ : $\mathrm{P}<0.05 ;\left({ }^{* *}\right)$ : $\mathrm{P}$ $<0.01$; (ns): not significant $(P \geq 0.05)$.

Fig. 3 - Relationship between soil penetration resistance (SPR) and lateral root length/main root length (a) and lateral root/main root dry mass (b), specific stem length (c), specific root length

(d), leaf mass ratio (e), stem mass ratio $(f)$, root mass ratio $(g)$, root/shoot ratio $(R / S)(h)$ in $Q$. castaneifolia seedlings. For each graph, the regression equation between responses and SPR and the coefficient of determination $\left(\mathrm{R}^{2}\right)$ are given. $(*): \mathrm{P}<0.05 ;(* *): \mathrm{P}$ $<0.01$; (ns): non-significant $(P \geq 0.05)$. Models and regression lines are not shown.
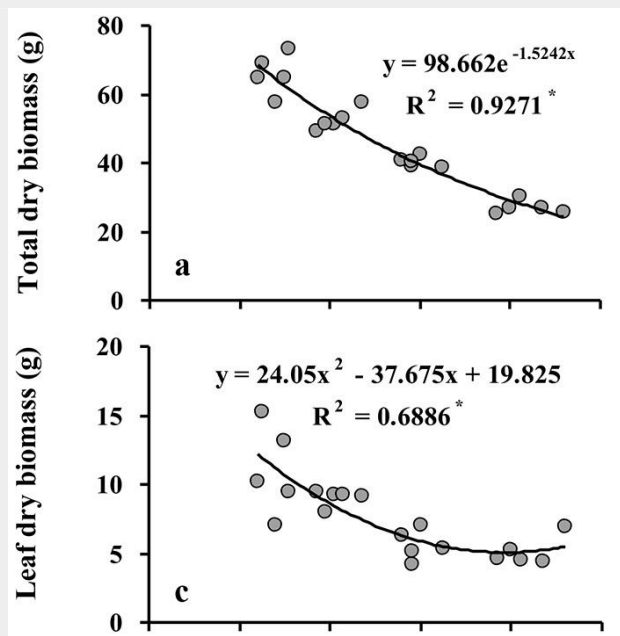

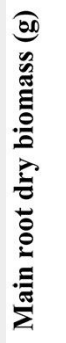

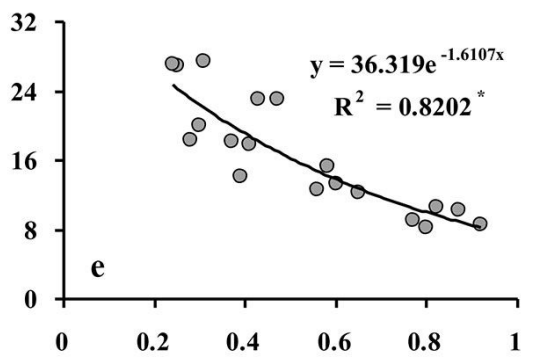

Penetration resistance (MPa)
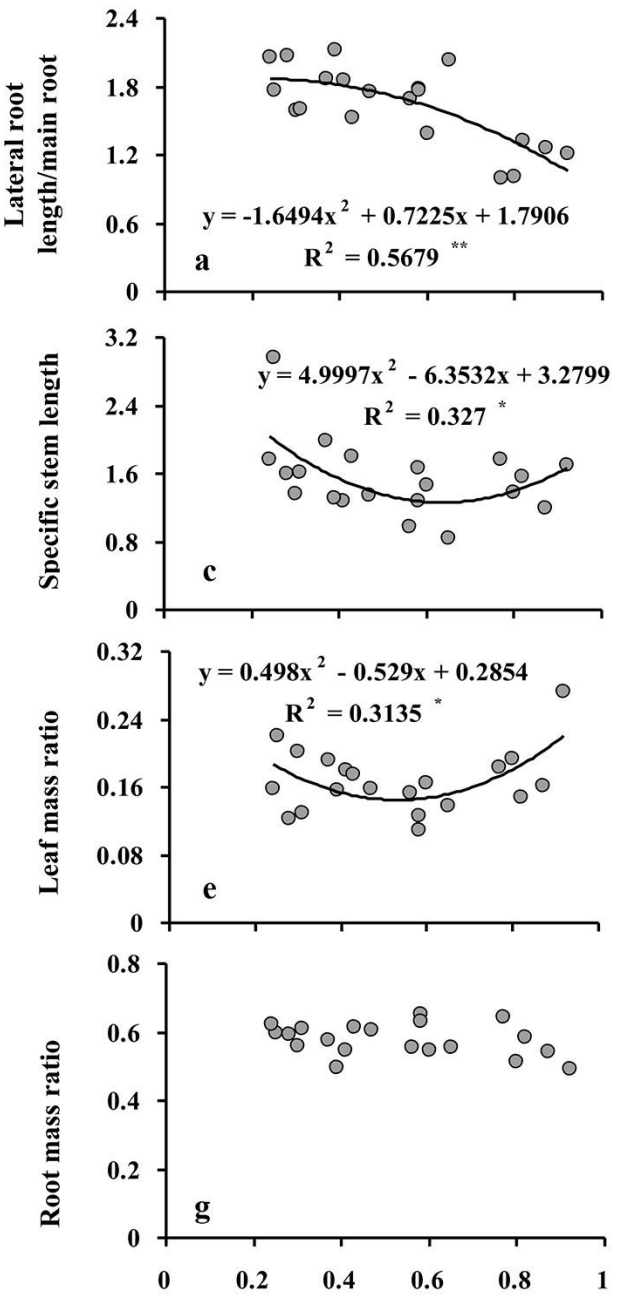

Penetration resistance (MPa)

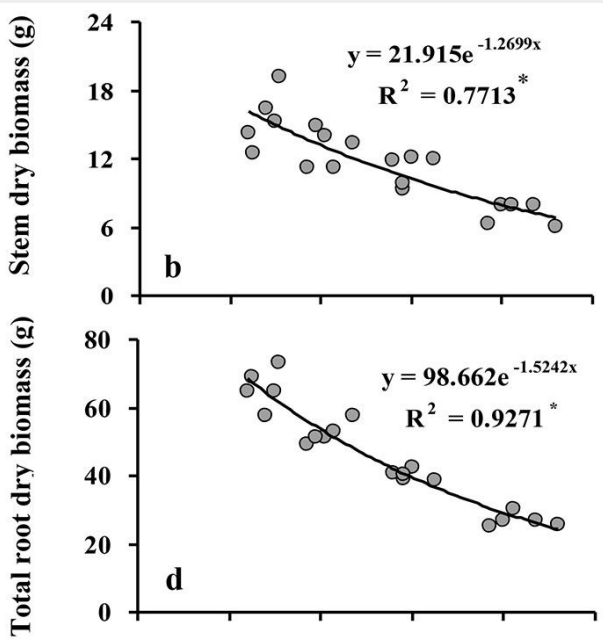

क्री

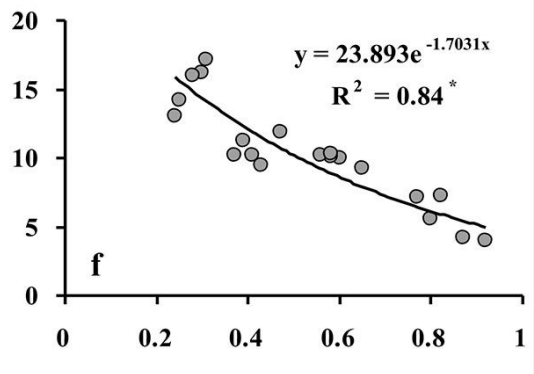

Penetration resistance (MPa)
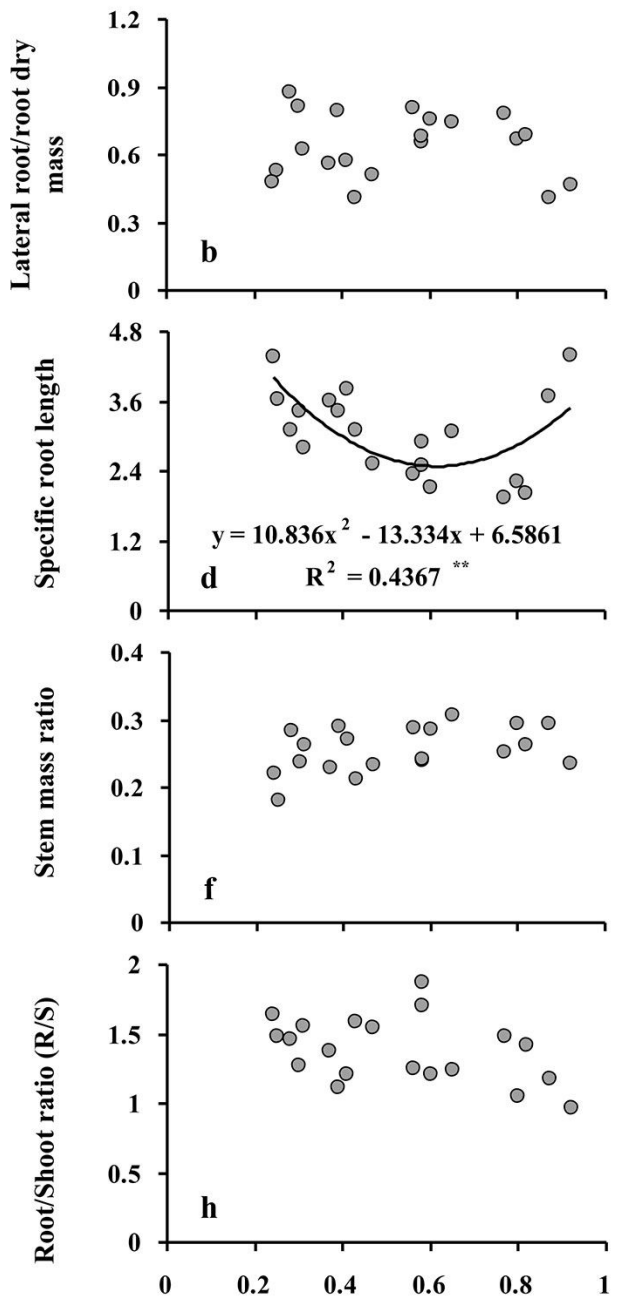

Penetration resistance (MPa) 
mass ratio (RMR), i.e., the fractions of total dry biomass in the stem and the root system, ranged between $24-27 \%$ (stem) and $56-60 \%$ (roots) and were not significantly different among the compaction treat ments (Tab. 2, Fig. 3f-g). Finally, the ratio of root to shoot biomass (R/S) was not significantly different among compaction treatments (Tab. 2, Fig. 3h).

\section{Discussion}

\section{Seedling morphology and growth}

Increasing soil compaction strongly affected the morphology and growth of $Q$. castaneifolia seedlings in the greenhouse and supported our first two hypotheses that increasing soil strength would cause decreases in all variables of above-ground and below-ground seedling sizes (morphology) and biomass (growth) of the whole seedling and all of its components (i.e., above-ground: stem length, stem diameter, leaf length; biomass of stems, shoots, leaves; below-ground: main root length, main root diameter, lateral root length; biomass of main root and lateral roots). Size and biomass variables indicate that the seedlings growing in the control treatments were at least twice the size and weight of seedlings growing in the high intensity compaction treatment (this was the case for the whole seedling and for almost every above-ground and belowground seedling component). Morphological changes of the root system, i.e., the length of lateral roots and dry biomass of the main and lateral roots were particularly striking, with reductions between $60-70 \%$. Shorter primary and lateral roots of lower biomass observed in compacted soils are consistent with previous findings that increased soil compaction diminishes root growth (Bassett et al. 2005, Bejarano et al. 2010) and support the argument that soil compaction is an important stress factor that can adversely affect the early development of tree seedlings (Kozlowski 1999). Reduced root penetration, in turn, may result in restricted access to, and adsorption of, nutrients and water (Blouin et al. 2008), leading to increases in leaf water deficits, decreases in photosynthetic rate, diminished sizes and growth of stems and the entire seedling, and even limited seedling survival under drought (Misra \& Gibbons 1996, Lloret et al. 1999, Gómez et al. 2002, Jordan et al. 2003, Alameda \& Villar 2012).

Although seedling morphology and growth exhibited consistent and predictable responses to different intensities of soil compaction in the current study, adverse effects from soil compaction are not universally observed. Soil compaction has even been reported to have a positive effect on total plant biomass, despite reductions in main root length, for some tree species over ranges of SPR comparable to our study (Alameda \& Villar 2009, Bejarano et al. 2010). While biomass ultimately decreased with increasing soil strength, nine out of 17 (53\%) deciduous and evergreen woody species had significant increases in total biomass with increasing soil strength up to 0.5 MPa (Alameda \& Villar 2009). The difference to the current study that revealed immediate decreases in biomass even below 0.5 MPa may be due to differences in soil texture and its effect on water stress. Soil water content at the time of compaction is an important determinant of the effect size of soil compaction on seedling morphology and growth. Because soil water lubricates soil particles along the elongating tip, it can alleviate excessive soil stress (Siegel-Issem et al. 2005, Day et al. 2010) such that higher soil water contents are typically associated with less severe effects on seedling growth and biomass (Blouin et al. 2008). Further, moderate compaction in soils of coarser texture can actually improve nutrient and water adsorption (Arvidsson 1999, Gómez et al. 2002). Thus, in the more sandy-textured soil (i.e., mixture of sand and peat) of Alameda \& Villar (2009), moderate intensity soil compaction may have facilitated greater root-soil contact (Alameda \& Villar 2009, 2012, Bejarano et al. 2010), while in the current study compaction of loamy- to clay-textured soils, which are more easily compactable than more coarsely-textured soils (Eckelmann et al. 2006), may have resulted in a lower percentage of water and air space, and perhaps more oxygen deficiency in the soil, and greater stress on plant root growth (Kozlowski 1999, Alameda \& Villar 2009). This could account for the immediate size and biomass reductions of Q. castaneifolia seedlings of $20-35 \%$ in this study, despite daily irrigation to maintain moist soil water conditions.

\section{Seedling architecture}

Our third hypothesis that increased soil compaction would cause differential growth allocation patterns to above- and below-ground portions, resulting in architectural changes to the seedlings, is mostly unsupported by our data. At first, the absence of architectural changes is somewhat surprising considering the concept of "functional equilibrium" in biomass allocation (Brouwer 1963, Iwasa \& Roughgarden 1984). Predicated on the assumption that biomass allocation is a strong driver of a plant's capacity to take up carbon, water, and nutrients, which strongly affects growth (Evans 1972), resource limitation feedbacks between shoot and root growth would ensure an increase in uptake of the most limiting factor to achieve some "balanced growth" (Shipley \& Meziane 2002), i.e., a functional equilibrium. Thus, if the limiting factor for plant growth were below-ground (e.g., water, nutrients) induced by soil compaction, a preferential biomass allocation to the roots would maintain a balance among leaves, stems, and roots, enabling theses organs to function most optimally by matching their physiological activities at the whole plant level (Poorter et al. 2012). In accordance with this model, plants typically respond to drought, for example, with a decrease in shoot biomass and an increase in root biomass (Gregory et al. 1997, Poorter et al. 2012), which increases the efficiency of soil exploration and water acquisition (Olmo et al. 2014).

Although plants under environmental or physical stress (e.g., removal of leaves or roots) are able to quickly restore allocation patterns to control levels (Brouwer 1963, Poorter \& Nagel 2000), recent research has revealed that plant responses in biomass allocation are generally modest or often entirely absent (Poorter et al. 2012). In fact, plants seem to be less able to adjust biomass allocation than to alter organ morphology and there is little support that plants use the mechanism of allocation to adjust to their environment (Reich 2002, Poorter et al. 2012). In this light, the lack of significant effects of soil compaction on almost all seedling architecture responses of Q. castaneifolia (i.e., SMR, LMR, RMR, $R / S, S S L, S R L$, and the ratio of lateral to main root dry biomass) is not surprising. Increasing soil compaction similarly failed to affect biomass allocation patterns to stems, leaves, and roots of Quercus pyrenaica Willd. (Bejarano et al. 2010) and to roots of Q. ilex subsp. ballota (Desf.) Samp., Q. canariensis Willd., and Q. pyrenaica Willd. (Alameda \& Villar 2009), although allocation patterns to the roots changed for Quercus coccifera L., Q. suber L., and Q. faginea Lam. (albeit both positive and negative) under soil compaction levels comparable to this study (Alameda \& Villar 2009). Further, R/S ratios typically increase with decreasing water availability (Gower et al. 1992, Schenk \& Jackson 2002), but following soil compaction, $\mathrm{R} / \mathrm{S}$ responses have been highly variable. $R / S$ ratios have increased in the case of $P$. contorta on dry, but not moist or wet, compacted soils (Blouin et al. 2008), decreased in the cases of Q. coccifera and Q. faginea (Alameda \& Villar 2009) and Pseudotsuga menziesii var. glauca (Beissn.) Franco and Pinus contorta Dougl. Ex. Loud. var. latifolia Engelm. on loamy soils in British Columbia (Conlin 1996), and remained unchanged in the cases of Q. ilex, Q. canariensis, and Q. pyrenaica and an additional eight out of 17 woody species under investigation (Alameda \& Villar 2009), as was also the case for Q. castaneifolia in this study. It seems clear, then, that generalizations regarding consistent mass ratio and $\mathrm{R} / \mathrm{S}$ changes in response to soil compaction are inadvisable, as responses are species specific and strongly dependent on environmental factors such as soil type and soil water content (Blouin et al. 2008), as well as light conditions (Bejarano et al. 2010).

Under conditions that limit growth, the functional equilibrium concept might suggest that the construction costs per root length would be minimized (i.e., greater $\mathrm{SRL}$ ) to enable a large soil volume to be exploited at small cost (Ryser 2006). 
Greater SRL has been found to be associated with relatively high rates of root proliferation in disturbed soil and opportunistic root growth (Eissenstat 1991). Increased SRL, a response of many species to drought (Metcalfe et al. 2008) enhance the root-soil interface and root adsorption potential (Ostonen et al. 2007), which is an advantage when soil water is limited. In contrast to Fraxinus angustifolia Vahl., where SRL was significantly reduced at bulk densities of $1.4 \mathrm{~g} \mathrm{~cm}^{-3}$ (the equivalent of moderate compaction in this study Alameda \& Villar 2012), and for Q. pyrenaica when SPR values exceeded $1 \mathrm{MPa}$ (Bejarano et al. 2010), soil compaction in this study did not significantly affect SRL of $Q$. castaneifolia, which may be related to differences in soil attributes. We conclude that our biomass allocation results for $Q$. castaneifolia reflect the highly differential responses of individual species and we might infer that a threshold compaction for Q. castaneifolia had not been reached in this study, whereupon opportunistic root growth and root proliferation might be precluded. Our results should be interpreted in the context of a soil strength gradient of 0.1-1.0 MPa that equals moderate compaction intensities in other studies, and a soil water supply that did not result in water stress at any time.

Nonetheless, the only significant change in seedling architecture in this study was a shift in allocation toward relatively longer main roots compared to lateral roots. However, this shift occurred only after soil compaction had reached a high intensity. Severe compaction of soil shortens roots but may also alter their branching patterns such that the roots become more branched and form more lateral roots (Kozlowski 1999). This was clearly not the case in this study, however. Rather, increased soil compaction seems to have particularly affected the proportion of fine roots and decreased the growth of secondorder roots, accompanied by a relatively smaller decrease in the growth of first root order (Alameda \& Villar 2012). Given that fine-roots are particularly active in water and nutrient uptake, such that a greater allocation of biomass to lateral roots would be expected under conditions of water stress, the observed greater proportional allocation of biomass to the main root would rather indicate an absence of much water stress. The specific reasons for favoring the lengths of the main over lateral roots, however, are not clear.

\section{Response thresholds}

While the relationships between soil strength and morphological response variables generally followed a negative exponential shape, indicating that the changes in seedling size variables were highest per unit increase of SPR at lower soil strengths, the relationships between soil strength and growth response variables were nearly linear, with the exception of fresh and dry leaf weights. While these mixed response shapes support our fourth hypothesis that increases in soil strength are not always linearly related to the morphological and growth response variables under study, we did not find any evidence of a threshold in soil strength that has to be exceeded before sizes and growth of above- and below-ground components of $Q$. castaneifolia seedlings become adversely impacted. In this study, soil compaction affected seedling morphology and growth of Q. castaneifolia seedlings even at a low compaction intensity. Our results thus extend findings that any increase in soil strength may restrict root growth of woody plants (Skinner et al. 2009) to above-ground portions of Q. castaneifolia seedlings. We conclude that growth limitations, particularly for root growth, may be induced at much lower soil strengths for some woody species than the often-cited soil strength threshold of 2-2.5 MPa (Greacen \& Sands 1980, Busscher et al. 1986, Siegel-Issem et al. 2005). While this critical value may be more applicable to survival than growth (Bulmer \& Simpson 2005), soil strength values below 2.5 MPa have been shown to reduce root growth of radiata pine (Pinus radiata D. Don. - Zhou et al. 2000), lodgepole pine (Blouin et al. 2008), and eucalyptus (Eucalyptus nitens Maiden - Misra \& Gibbons 1996) and soil strengths as low as $0.6 \mathrm{MPa}$ might pose a barrier to the regeneration of cabbage tree (Cordyline australis G. Forst. - Bassett et al. 2005). While we did not evaluate seedling mortality as a function of soil compaction in this study, our results show that for most seedling morphology and growth responses of Q. castaneifolia seedlings there is a non-linear inverse relation with SPR, with largest effect sizes at low compaction intensities and no threshold value for SPR to be exceeded for growth limitations of Q. castaneifolia seedlings to occur. On the other hand, it appears that soil compaction can eventually increase the root mass ratio in some species, but only at severe compaction (Poorter et al. 2012) well beyond the levels obtained in this study. In this study, however, soil compaction may have been too low to divert significant growth resources either from (Alameda \& Villar 2009) or toward (Alameda \& Villar 2009, Poorter et al. 2012) the root system of Q. castaneifolia. Alternatively, our failure to detect significant increases in the root mass ratio, $\mathrm{SRL}$, and $\mathrm{R} / \mathrm{S}$ ratio, may also be due to the lack of water stress in our experiment.

\section{Conclusions}

The present study investigated changes in seedling morphology, growth, and architecture following experimentally set soil compaction levels under conditions that controlled for differences in soil texture and soil water regimes known to confound the effects of soil compaction in the field. SPR, the metric for soil compaction used in this study, is very sensitive to differences in soil texture and water content, which makes narrow extrapolations of any single compaction study result to different soil conditions challenging. While it is therefore difficult to exactly predict how much harvesting traffic would be required to reproduce identical levels of SPR in soils with different textures and water contents, the changes in seedling morphology, growth, and architecture in response to increasing soil strength are more readily generalizable. Our results clearly show that in soils of a loam to clay-loam texture with optimal conditions of water and soil strengths of up to 1.0 MPa, an increased soil compaction: (1) causes morphological changes to above- and below-ground portions of $Q$. castaneifolia seedlings (i.e., smaller sizes); (2) causes decreased growth (biomass) responses of the whole plant and all of the plant's components (e.g., stem, shoot, leaves, roots); (3) does not cause significant, differential growth allocation patterns to above- and below-ground portions that result in architectural changes to the seedlings, thus making plant architecture a less sensitive response to increased soil compaction than size/growth and not a very reliable predictor of size/growth responses; (4) typically results in non-linear size and growth responses with large negative effects at low soil compaction intensities; and (5) does not exhibit a critical soil threshold before size and growth responses become adversely affected.

\section{List of abbreviations}

The following abbreviations were used throughout the manuscript:

-SPR: soil penetration resistance

- BD: bulk density

- TP: total porosity

- PD: particle density

- SSL: specific stem length

- SRL: specific root length

- SMR: stem mass ratio

- LMR: leaf mass ratio

- RMR: root mass ratio

- R/S: root-to-shoot ratio

\section{Acknowledgements}

The authors would like to acknowledge the financial support of the Iran National Science Foundation (INSF), project No. 93014726. We thank two anonymous reviewers for their helpful comments which improved the manuscript.

\section{References}

Acácio V, Holmgren M, Jansen PA, Schrotter O (2007). Multiple recruitment limitation causes arrested succession in Mediterranean cork oak systems. Ecosystems 10: 1220-1230. - doi: 10.1007/s10021-007-9089-9

Alameda D, Villar R (2009). Moderate soil compaction: implications on growth and architecture in seedlings of 17 woody plant species. Soil and Tillage Research 103: 325-331. - doi: 10.1016/ j.still.2008.10.029

Alameda D, Villar R (2012). Linking root traits to 
plant physiology and growth in Fraxinus angustifolia Vahl. seedlings under soil compaction conditions. Environmental and Experimental Botany 79: 49-57. - doi: 10.1016/j.envexpbot.20 12.01.004

Ampoorter E, Goris R, Cornelis WM, Verheyen K (2007). Impact of mechanized logging on compaction status of sandy forest soils. Forest Ecology and Management 241: 162-174. - doi: 10.1016 /j.foreco.2007.01.019

Arvidsson J (1999). Nutrient uptake and growth of barley as affected by soil compaction. Plant and Soil 208: 9-19. - doi: 10.1023/A:1004484518 652

Bassett IE, Simcock RC, Mitchell ND (2005). Consequences of soil compaction for seedling establishment: implications for natural regeneration and restoration. Australian Ecology 30: 827-833. - doi: 10.1111/j.1442-9993.2005.01525.x Bejarano MD, Villar R, Murillo AM, Quero JL (2010). Effects of soil compaction and light on growth of Quercus pyrenaica Willd. (Fagaceae) seedlings. Soil and Tillage Research 110: 108-114. - doi: 10.1016/j.still.2010.07.008

Blouin VM, Schmidt MG, Bulmer CE, Krzic M (2008). Effects of compaction and water content on lodgepole pine seedling growth. Forest Ecology and Management 255: 2444-2452. - doi: 10.1016/j.foreco.2008.01.008

Brouwer R (1963). Some aspects of the equilibrium between overground and underground plant parts. Jaarboek van het Instituut voor Biologisch en Scheikundig onderzoek aan Landbouwgewassen 1963: 31-39.

Bulmer CE, Simpson DG (2005). Soil compaction and water content as factors affecting the growth of lodgepole pine seedlings on sandy clay loam soil. Canadian Journal of Soil Science 85: 667-679. - doi: 10.4141/So4-055

Busscher WJ, Sojka RE, Doty CW (1986). Residual effects of tillage on coastal plain soil strength. Soil Science 141: 144-148. - doi: 10.1097/00010 694-198602000-00007

Choi JH, Chung GC, Suh SR, Yu JA, Sung JH, Choi KJ (1997). Suppression of calcium transport to shoots by root restriction in tomato plants. Plant and Cell Physiology 38: 495-498. - doi: 10.1093/oxfordjournals.pcp.a029195

Conlin TSS (1996). Soil compaction studies. FRDA Rep. No. 264, Canadian Forest Service, Victoria, BC, Canada. pp. 14.

Corns GW (1988). Compaction by forestry equipment and effects on coniferous seedling growth on four soils in the Alberta foothills. Canadian Journal of Forest Research 18: 75-84. doi: 10.1139/x88-012

Day SD, Bassuk NL (1994). A review of the effects of soil compaction and amelioration treatments on landscape trees. Journal of Arboriculture 20: 9-17.

Day SD, Wiseman PE, Dickinson SB, Harris JR (2010). Tree root ecology in the urban environment and implications for a sustainable rhizosphere. Arboriculture and Urban Forestry 36: 193-205.

Dickerson BP (1976). Soil compaction after treelength skidding in northern Mississippi. Soil Science Society of America Journal 40: 965-966. doi: $10.2136 /$ sssaj1976.03615995004000060043 $\mathrm{x}$

Eavis BW (1967). Mechanical impedance to root growth. In: Proceeding of the "Agricultural Engineering Symposium”. Report no. 4/F/39, The Institute of Agricultural Engineering, Silsoe, UK, pp. 11.

Eckelmann W, Baritz R, Bialousz S, Bielek P, Carre F, Houšková B, Jones RJA, Kibblewhite MG, Kozak J, Le Bas C, Tóth G, Tóth T, Várallyay G, Yli Halla M, Zupan M (2006). Common criteria for risk area identification according to soil threats. European Soil Bureau Research Report No. 20, EUR 22185 EN, Office for Official Publications of the European Communities, Luxembourg, pp. 94.

Eissenstat DM (1991). On the relationship between specific root length and the rate of root proliferation: a field study using citrus rootstocks. New Phytologist 118: 63-68. - doi: 10.1111/ j.1469-8137.1991.tbo0565.x

Evans GC (1972). The quantitative analysis of plant growth. Blackwell Scientific Publications, Oxford, UK and University of California Press, Berkeley, CA, USA, pp. 734.

Gómez A, Powers RF, Singer MJ, Horwath WR (2002). Soil compaction effects on growth of young ponderosa pine following litter removal in California's Sierra Nevada. Soil Science Society of America Journal 66: 1334-1343. - doi: 10.2136/sssaj2002.1334

Gower ST, Vogt KA, Grier CC (1992). Carbon dynamics of Rocky Mountain Douglas-fir: influence of water and nutrient availability. Ecological Monographs 62: 43-65. - doi: 10.2307/2937170 Grace JM, Skaggs RW, Cassel DK (2006). Soil physical changes associated with forest harvesting operations on an organic soil. Soil Science Society of America Journal 70: 503-509. doi: 10.2136/sssaj2005.0154

Greacen EL, Sands R (1980). Compaction of forest soils. Australian Journal of Soil Research 18: 163-189. - doi: 10.1071/SR9800163

Gregory PJ, Palta JA, Batts GR (1997). Root systems and root: mass ratio-carbon allocation under current and projected atmospheric conditions in arable crops. Plant and Soil 187: 221228. - doi: 10.1007/BFo0017089

Grigal DF (2000). Effects of extensive forest management on soil productivity. Forest Ecology and Management 138: 167-185. - doi: 10.1016/S0378-1127(00)00395-9

Horn R, Taubner H, Wuttke M, Baumgartl T (1994). Soil physical properties related to soil structure. Soil and Tillage Research 30: 187-216. - doi: 10.1016/0167-1987(94)90005-1

Iwasa Y, Roughgarden J (1984). Shoot/root balance of plants: optimal growth of a system with many vegetative organs. Theoretical Population Biology 25: 78-105. - doi: 10.1016/00405809(84)90007-8

Jordan D, Ponder F, Hubbard VC (2003). Effects of soil compaction, forest leaf litter and nitrogen fertilizer on two oak species and microbial activity. Applied Soil Ecology 23: 33-41. - doi: 10.1016/So929-1393(03)00003-9

Jourgholami M (2014). Forest harvesting plan of Namkhaneh district. Faculty of Natural Resources Press, Karaj, Iran, pp. 125.

Kabzems R, Haeussler S (2005). Soil properties, aspen and white spruce responses five years after organic matter removal and compaction treatment. Canadian Journal of Forest Research 35: 2045-2055. - doi: 10.1139/x05-175
Kozlowski TT (1999). Soil compaction and growth of woody plants. Scandinavian Journal of Forest Research 4: 596-619. - doi: 10.1080/ 02827589908540825

Lloret F, Casanovas C, Peñuelas J (1999). Seedling survival of Mediterranean shrubland species in relation to root, shoot ratio, seed size and water and nitrogen use. Functional Ecology 13: 210-216. - doi: 10.1046/j.1365-2435.1999. 00309.x

Masle J (2002). High soil strength: mechanical forces at play on root morphogenesis and in root: shoot signaling. In: "Plant roots, the hidden half. 3rd edn" (Waisel Y, Eshel A, Kafkafi U eds). Marcel Dekker, New York, USA, pp. 807819 .

Metcalfe DB, Meir P, Aragão L, Da Costa ACL, Braga AP, Gonçalves PHL, Silva JD, De Almeida SS, Dawson LA, Malhi Y, Williams M (2008). The effects of water availability on root growth and morphology in an Amazon rainforest. Plant and Soil 311: 189-199. - doi: 10.1007/s11104-008-96709

Misra RK, Gibbons AK (1996). Growth and morphology of eucalypt seedling roots in relation to soil strength arising from compaction. Plant and Soil 182: 1-11. - doi: 10.1007/BF00010990

Olmo M, Lopez-Iglesias B, Villar R (2014). Drought changes the structure and elemental composition of very fine roots in seedlings of ten woody tree species. Implications for a drier climate. Plant and Soil 384: 113-129. - doi: 10.1007/s11104-014-2178-6

Ostonen I, Püttsepp U, Biel C, Alberton O, Bakker MR, Lõhmus K, Majdi H, Metcalfe D, Olsthoorn AFM, Pronk A, Vanguelova E, Weih M, Brunner I (2007). Specific root length as an indicator of environmental change. Plant Biosystems 141: 426-442. - doi: 10.1080/112635007016 26069

Poorter H, Nagel O (2000). The role of biomass allocation in the growth response of plants to different levels of light, $\mathrm{CO}_{2}$, nutrients and water: a quantitative review. Australian Journal of Plant Physiology 27: 595-607. - doi: 10.1071/ PP99173_CO

Poorter H, Niklas KJ, Reich PB, Oleksyn J, Poot P, Mommer L (2012). Biomass allocation to leaves, stems and roots: meta-analyses of interspecific variation and environmental control. New Phytologist 193: 30-50. - doi: 10.1111/j.1469-8137.20 11.03952.x

Reich P (2002). Root-shoot relations: optimality in acclimation and adaptation or the "Emperor's new clothes?" In: "Plant roots, the hidden half ( $3^{\text {rd }}$ edn)" (Waisel Y, Eshel A, Kafkafi U eds). Marcel Dekker, New York, USA, pp. 205220.

Ryser $P$ (2006). The mysterious root length. Plant and Soil 286: 1-6. - doi: 10.1007/s11104-0069096-1

Schenk HJ, Jackson RB (2002). Rooting depths, lateral root spreads and below-ground/aboveground allometries of plants in water-limited ecosystems. Journal of Ecology 90: 480-494. doi: 10.1046/j.1365-2745.2002.00682.x

Shipley B, Meziane D (2002). The balancedgrowth hypothesis and the allometry of leaf and root biomass allocation. Functional Ecology 16: 326-331. - doi: 10.1046/j.1365-2435.2002. 00626.x 
Siegel-Issem CM, Burger JA, Powers RF, Ponder $F$, Patterson SC (2005). Seedling root growth as a function of soil density and water content. Soil Science Society of America Journal 69: 215226. - doi: 10.2136/sssaj2005.0215

Skinner AK, Lunt ID, Spooner P, Mclntyre S (2009). The effect of soil compaction on germination and early growth of Eucalyptus albens and an exotic annual grass. Austral Ecology 34:
698-704. - doi: 10.1111/j.1442-9993.2009.01977.x Souch CA, Martin PJ, Stephens W, Spoor G (2004). Effects of soil compaction and mechanical damage at harvest on growth and biomass production of short rotation coppice willow. Plant and Soil 263: 173-182. - doi: 10.1023/B: PLSO.0000047734.91437.26

Talebi KS, Sajedi T, Pourhashemi M (2014). Forests of Iran: a treasure from the past, a hope for the future. Plant and Vegetation 10, Springer. pp. 152. [online] URL: http://library. wur.nl/WebQuery/clc/2042694

Zhou C, Penfold C, Sands R, Misra RK, Hudson I (2000). Effects of soil air-filled porosity, soil matric potential and soil strength on primary root growth of radiate pine seedlings. Plant and Soil 236: 105-115. - doi: 10.1023/A:101199 4615014 